\title{
Distilled Water
}

National Cancer Institute

\section{Source}

National Cancer Institute. Distilled Water. NCI Thesaurus. Code C82681.

An ultra-pure form of water with potential antineoplastic activity. Derived by boiling impure water and condensing the resultant steam in a sterile container, distilled water has been shown to kill bladder cancer cells in vitro through osmotic lysis (cytolysis) 